\title{
Islamic Banks' Role in Serving the Poor Unbanked Population in Pakistan
}

\author{
Sohail Kamran ${ }^{1 *}$, Muhammad Ayub ${ }^{2}$, Adeel Luqman ${ }^{3}$ \\ ${ }^{1}$ Assistant Professor, Department of Business Administration, Fatima Jinnah Women University, \\ Rawalpindi, Pakistan \\ ${ }^{2}$ Director Research and Editor, Journal of Islamic Business and Management, \\ Riphah International Islamic University, Islamabad, Pakistan \\ ${ }^{3}$ Assistant Professor, Department of Business Administration, Fatima Jinnah Women University, \\ Rawalpindi, Pakistan
}

\section{Keywords}

Islamic Banking

Islamic Financial Institutes

Exclusion

Poor Unbanked

Social Inclusion

Pakistan

Received: 14 October 2018

Accepted: 19 November 2018

\begin{abstract}
One of the primary objectives of Islamic financial institutions is to enhance public wellbeing by alleviating marketplace inequality and injustice. The poor individuals are typically excluded from the basic financial service, and the resultant exclusion impedes their wellbeing. It puts them at a disadvantage compared to mainstream banking customers and raises issues of various sorts in their lives. The main objective of this paper is to suggest viable propositions to Islamic banks to facilitate poor individuals' financial inclusion and welfare. In so doing, the paper, through a literature review, comprehends barriers preventing the poor to own a bank account and the harmful effects of financial exclusion that they encounter in their routine lives. Islamic banks, by dint of their specific nature and philosophy, have a potential to help financial inclusion of economically susceptible population. But, Islamic banks have so far not availed the opportunity of involving the masses at the grassroots level and thus enhancing their outreach by serving the unbanked poor individuals. Based on the understanding developed from the literature survey, we discuss the potential role of Islamic banks in financial inclusion of the poor in Pakistan and elsewhere, which could mitigate sufferings of the poor owing to their financial exclusion. By way of financial inclusion of the poor, Islamic banks will also be fulfilling their Corporate Social Responsibility (CSR), the hallmark of public policies in the context of the World Bank's Sustainable Development Goals (SDGs). Finally, the paper provides valuable future research avenues in Islamic banking field..
\end{abstract}

KAUJIE Classification: E33, H13, H49, I23, N0, N6

JEL Classification: D63, G21, P46, Z12

(C) 2018 JIBM. All rights reserved.

\footnotetext{
*Corresponding author: Sohail Kamran

${ }^{\dagger}$ Email: sohail@fjwu.edu.pk
} 


\section{INTRODUCTION}

Over five billion world's inhabitants live on different levels of poverty (Fisk et al., 2016), but poverty is more prevalent in developing countries. For instance, over $80 \%$ of the Pakistani population lives on different levels of poverty i.e., poor and low-income consumers (Kochar, 2015). The poor consumers live on 2 USD or below a day, while low-income consumers live on 10 USD or below per day (Kochar, 2015). Service firms, also including the banks and other financial institutions, commonly deny access of basic services to poor customers owing to their lack of profitability (e.g., Kamran \& Uusitalo, 2019; Kempson \& Whyley, 1999). Service firms' discrimination to serve poor individuals often creates problems in their lives (Kamran \& Uusitalo, 2016b; Wang \& Tian, 2014). These discriminatory practices of service firms raise several ethical issues in contemporary business system (Kennedy \& Laczniak, 2016; Kotler \& Levy, 1971). The business practices that result into exclusion and marginalization of poor individuals ought to be discouraged and reversed as the exclusion causes severe detriment to them (Kamran \& Uusitalo, 2016a; 2016b; Kotler \& Levy, 1971).

It is necessary for individuals' smooth business and living that they have an access to transaction banking, savings, credits and insurance (World Bank, 2005). However, many citizens of developing nations are completely excluded from the mainstream financial services and, as such; they are termed as 'unbanked' (Solo, 2008). Developing nations' inhabitants mostly lack access to essential financial services (Demirguc-Kunt, Klapper, Singer, \& Van Oudheusden, 2015).

The poor unbanked individuals undergo different kinds of detriment in their ordinary lives. Their poverty coupled with illiteracy is cited as one of the major causes of their financial exclusion (Kamran \& Uusitalo, 2016a). The poor customers face several barriers to banking in Pakistan and elsewhere, which hinders their wellbeing and expose them to harm (e.g., Kamran \& Uusitalo, 2019; Kemspon, 2006). It is well documented that banks discriminate to serve poor individuals due to their lesser potential to raise revenues (Kempson \& Whyley, 1999; Kamran \& Uusitalo, 2019). In Pakistan, over $85 \%$ adults are unbanked (Demirguc-Kunt et al., 2015). Commercial banks' unreceptive attitude towards the economically disadvantaged customers is frequently highlighted as a key reason of their exclusion from the basic banking services (Kamran \& Uusitalo, 2019; Kemspon, 2006; Wang \& Tian, 2014; ).

This paper's main objective is to analyze the potential of Islamic banks in serving the poor unbanked population in Pakistan. In so doing, we have analyzed the impediments in their financial inclusion and harmful effects of financial exclusion surfacing in the lives of the poor. It is a well acknowledged fact that poor customers are avoided by banks due to their limited financial product needs which results in lesser revenue generation for commercial banks (Claessens, 2006). That's why poor individuals have a higher possibility to be excluded from basic banking services (Carbo, Gardener, \& Molyneux, 2007; Kempson \& Whyley, 1999).

Poor individuals lack ability and resources to improve their position in the society and to raise voice against the unfairness that they encounter at the marketplace in various service settings (Fisk et al., 2016). They are helpless due to their poverty and illiteracy (Kamran 
\& Uusitalo, 2019). Likewise, the factors like the lack of knowledge and education, sociocultural deprivation (Karnani, 2009, p. 78) and banks discrimination to serve them hinder their financial inclusion. Parties in a position of strength (e.g., banking regulator and researchers), can give voice to the powerless poor customers, who face exclusion from mainstream banking services due to their susceptible financial position in the society. They can facilitate poor individuals' wellbeing by supporting their financial inclusion and by proposing viable routes to financial service institutions to serve the unbanked (Kamran \& Uusitalo, 2019).

\section{EFFORTS UNDERWAY FOR FINANCIAL INCLUSION}

A lot of efforts aimed at reducing the exclusion or enhancing financial inclusion are underway in the world, particularly by the multi-lateral institutions like the World Bank Group (WBG). The Financial Inclusion Support Framework (FISF) of the WBG makes grant funds available through region-led technical assistance projects that enable Bank to provide multiyear technical-assistance programs to match countries' multi-year financial inclusion and financial literacy strategies and targets (World Bank, 2018). To avail the opportunity, the Jeddah based Islamic Development Bank (IDB) has also entered into an arrangement to mutually enhance the financial inclusion in Islamic countries (World Bank and Islamic Development Bank Group, 2016).

There are over 450 Islamic Financial Institutions (IFIs) operating in various parts of the world (Islam, Alam, \& Hossain, 2014; Rashid, Riaz, \& Zaffar, 2018) and their main purpose is said to be enhancing the wellbeing of humanity (Dusuki, 2008; Hasan, Ali, \& Muhammad, 2018). Hence, the IFIs are expected to be working, side by side doing business for profits, to enhance social and public wellbeing by alleviating poverty and inequality (Dusuki, 2008, World Bank and Islamic Development Bank Group, 2016). The IMF Directors in their meeting held in May 2018 accepted that growth of Islamic finance, with its unique features, presents good opportunities to enhance financial inclusion, deepen financial markets, and mobilize funding for development by offering new modes of finance and attracting "unbanked" population that have not participated in the financial system. Therefore, the IFIs can certainly facilitate to improve financial inclusion of the poor, who are excluded (i.e., unbanked) from the mainstream financial system (Ayub, 2018).

Pakistan has a massive unbanked and poor population. However, the commercial banks tend to avoid serving vulnerable population of society due to their earnings maximization goals (Kamran \& Uusitali, 2019). Islamic banking has the potential to provide an alternative to poor population to access basic financial services in Pakistan and elsewhere. In March 2018, Five Islamic banks were operating in Pakistan. In addition, sixteen commercial banks having separate Islamic banking branches were also providing Islamic banking services. Total number of Islamic banking branches stood at 2,589 in March, 2018 (State Bank of Pakistan, 2018). The overall market share that Islamic banks could get in the Pakistani banking industry over the last 15 years remains a little less than $15 \%$ (State Bank of Pakistan, 2018). These figures suggest that Islamic banks need to enhance their overall 
market share by offering innovative offerings for financing the real sectors in the economy and penetrating those segments which are overlooked by the conventional banks. As discussed above, massive unbanked population in the country offers an opportunity to Islamic banks to expand their customer base and to position them as socially responsible business organisations. Islamic banks could certainly help the financially vulnerable population to be included to the basic financial services owing to their orientation to enhance human wellbeing (Dusuki, 2008; Hasan et al., 2018).

This paper highlights the barriers faced by the unbanked individuals to access basic banking services. In other words, it explicates major causes of financial exclusion and their consequences to those who are excluded from the mainstream banking services. It then offers managerial implications for the Islamic banks in Pakistan to better serve the financially excluded or unbanked individuals. The managerial implications are provided with an intention to enhance poor customers' financial inclusion and market share of Islamic banks. Given the fact that research on the issues of financial exclusion in the field of marketing is lacking (Koku, 2015), this conceptual paper is expected to be a valuable addition to the current literature on Islamic banking because it offers viable suggestions for serving the financially excluded individuals and enhancing Islamic banks market share in Pakistan.

\section{REASONS AND EFFECTS OF FINANCIAL EXCLUSION}

A thematic analysis of literature regarding financial exclusion has been conducted to find out the possible reasons and effects of financial exclusion on the unbanked population. The reasons of financial exclusion could be considered as obstacles to baking for the unbanked population. The literature review helps us to highlight major barriers impeding financial inclusion and wellbeing of the poor. The purpose is to suggest some viable paths to Islamic banks to assist financial inclusion of poor unbanked individuals and to suggest future research agenda related to the issue of financial exclusion. The ultimate objective, therefore, is to discuss the possible role of Islamic banks to enhance financial inclusion of the poor.

The review of literature regarding financial exclusion has resulted into various themes and sub-themes which are labeled as (i) Personal factors including the subthemes of poverty and lack of education of unbanked individuals (ii) Socio-cultural factors including the subthemes of family members influence on individuals intention to open a bank account, religious reasons and salaries paid by employers in cash, and (iii) Institutional reasons encompassing subthemes of deposit requirement to open a bank account, documentation required to open a bank account, physical access issues to bank branches, and the customer service related issues faced by the poor customers.

The literature analysis regarding the harmful effects of financial exclusion has resulted into three main themes in terms of the impact (i) Personal harm (ii) Social harm (iii) Economic harm. First, this paper addresses the reasons of financial exclusion, and subsequently it addresses harmful effects of financial exclusion upon the unbanked individuals. 


\section{Personal Factors}

Individual factors which may hinder the poor to open a basic bank account include their vulnerable economic situation and their illiteracy or lack of education (Kempson \& Whyley, 1999). Some poor individuals perceive that they don't need to own a bank account because they lack money. Likewise, poor individuals are commonly found to have little or no formal education, which also obstructs their financial inclusion. They find it difficult to gather and understand basic banking services information (Kamran \& Uusitalo, 2016a; 2016b). Although, unbanked individuals' poor financial and educational achievements are one of the major causes of their exclusion from the mainstream banking services (Kamran \& Uusitalo, 2016a; Kempson \& Whyley, 1999); nevertheless, the banks' unwelcoming behavior and strategies are also a source of exclusion (Kamran \& Uusitalo, 2019). The poor are on a higher risk of being excluded from the basic banking services because the banks don't focus their marketing communications towards them. They are considered an unproductive segment of the society (Kempson \& Whyley, 1999). This surely causes no or little knowledge about the benefits of using basic banking products among poor customers segment.

There is an element of self-imposed financial exclusion amongst some poor individuals who choose not to open a bank account owing to their personal choice and perceptions, or due to the negative word of mouth regarding banks within the poor customers social networks (Kamran \& Uusitalo, 2016a; Kempson \& Whyley, 1999); But, unwelcoming strategies and lack of marketing communications targeted at poor segments deepen their perceptions' that they require significant amount of money to operate a bank account. So, banks' unwelcoming strategies towards the poor complement their personal circumstances, which ultimately become a source of their exclusion from basic banking services (Kamran \& Uusitalo, 2016a; 2016b; Kamran \& Uusitalo, 2019; Kempson \& Whyley, 1999).

\section{Socio Cultural Reasons}

There can be various socio-cultural reasons fostering financial exclusion (Kempson, Whyley, Caskey, \& Collard, 2000), which could be manifested in shape of family members' influence on individuals' intention to open bank account (Kamran and Uusitalo, 2016a; Kempson \& Whyley, 1999). Religious reasons (Kamran \& Uusitalo, 2016a; Kempson \& Whyley, 1998) and salaries paid by the firms to their employees in cash form (Kamran \& Uusitalo, 2016a) are also the reasons.

The literature highlights that family members could adversely influence an individual's intention to open a bank account. These reasons were found to be true both in the developed world context e.g., the UK (Kempson \& Whyley, 1999) and in a developing country setting like Pakistan (Kamran \& Uusitalo, 2016a). The literature on financial exclusion also underscores that some Muslims could resist opening a bank account owing to their religious beliefs (Kamran \& Uusitalo, 2016a; Kempson and Whyley, 1998). Kempson and Whyley (1998) study highlights that some Pakistani and Bangladeshi origin Muslims residing in the UK resist conventional banking products as those are prohibited under the Islamic law (Kempson \& Whyley, 1998). A study of Kamran and Uusitalo (2016a) indicates that some poor unbanked consumers also realize that it is forbidden in Islam to obtain interest on the 
money kept in banking account, which becomes one of the sources of financial exclusion. Lastly, wages paid in cash form also are a reason of financial exclusion of poor in Pakistan. Many poor individuals work in informal sector and the employers generally pay their wages in cash form. In addition, informal employers that are abundant in undocumented part of the Pakistan's economy don't usually give the employment agreements to their employees. Thus, some unbanked poor individuals fail to comply with the documentary conditions for opening a bank account. The commercial banks used to ask their new customers to bring proof of income and letter of employment/business proof along with bank account opening form (Kamran \& Uusitalo, 2016a).

\section{Institutional Reasons Nurturing Financial Exclusion of the Poor Individuals}

The institutional barriers to financial inclusion of the poor include documentation and initial deposit requirements to open a bank account (Kempson, 2006; Kempson, Atkinson, \& Pilley, 2004) that create problems in accessing the banks by the poor. It may also be due to long distance to the banks' branches causing any customers service related problems faced in visiting the banks (Kamran \& Uusitalo, 2019; Kempson, 2006). Firstly, the account opening requirements sometimes hinder poor customers' inclusion to mainstream financial services (Kamran \& Uusitalo, 2016a; Kempson, 2006; Solo, 2008). Customers who wanted to open a bank account in Pakistan were asked to provide their source of income and employment or business details. Apparently, it was usually not easy for the poor employed in informal sectors to provide such documentation to banks for opening a bank account. Many poor individuals run their small businesses or work in different informal jobs and their employers don't offer them any written job agreements. Therefore, it was difficult for them to provide income and employment proof to banks for account opening. Likewise, some poor customers find it difficult to give initial deposit for opening a bank account (Kamran \& Uusitalo, 2016a).

However, towards the end of 2015, the regulator (State Bank of Pakistan) instructed the commercial banks in Pakistan to remove some documentary and initial deposit conditions to ease the process of bank account opening for the Pakistani poor customers (Kamran \& Uusitalo, 2016a; Kamran \& Uusitalo, 2019). Many poor unbanked individuals have been found to encounter issues in accessing physical bank branches in various countries of the world. In the developed world, however, this is a trivial cause of financial exclusion. For example, Kempson and Whyley (1999) reported that merely $1 \%$ of the unbanked or totally financially excluded households mentioned that non-availability of a bank outlet in close proximity of their homes was a major cause of their exclusion from the formal banking services. However, in the developing countries, banks decision makers tend not to open bank branches in the poor neighborhoods, in remote and rural areas. Therefore, the poor and rural area residents of developing countries face physical access barriers to mainstream financial services as majority of the population is poor and lives in villages. Studies by Kamran and Uusitalo (2016a; 2019) highlighted this issue in the Pakistani context where more than half of the population resides in villages and the people living there had to encounter problems in accessing banks. 
The banks negative response to less affluent customers is also cited as one of the major reasons of financial exclusion in developed (Kempson, 2006; Kempson \& Whyley, 1999) as well as in the developing countries (e.g., Kamran \& Uusitalo, 2016). Service firms are considered ethical when they treat the vulnerable customers in respectful manner (Rendtorff, 2009). The poor customers need assistance from the frontline staff of the commercial banks in their account opening endeavors. However, they are often treated unfairly by the bank staff. The study by Kamran and Uusitalo (2019) highlights that poor customers are given poor service by the commercial banks' staff, and they encounter disrespectful and discriminatory behavior and procedures from the banks employees while visiting banks for basic bank account opening.

The poor are vulnerable customers who need extra help from banks frontline staff in bank account opening endeavours (Brennan, 2006; Kamran \& Uusitalo, 2019). However, the literature highlights that banks are unsupportive to the poor unbanked customers (e.g., Kamran \& Uusitalo, 2019; Solo, 2008). It is due to the reason that the poor have normally meager resources and therefore, they are not expected to bring higher profits to banks. Developing economies have higher rates of unbanked population (Demirguc-Kunt et al., 2015) owing to widespread poverty (Kochhar, 2015). Claessens (2006) notes that developing nations banking system tends to serve affluent customers as it help banks to save costs and enhance profitability. Thus, the poor individuals suffer lack of access to basic banking products, which adversely affects their wellbeing.

The next section highlights the negative consequences that poor individuals encounter due to their financial exclusion.

\section{HARMFUL EFFECTS OF FINANCIAL EXCLUSION ON POOR UNBANKED INDIVIDUALS}

The extant literature indicates that financially excluded individuals undergo several repercussions in their lives. It indicates that financially excluded consumers face personal, social and economic issues in their lives (e.g., Collard \& Kempson, 2005; Kempson \& Whyley, 1998; Kempson \& Whyley, 1999; Solo, 2008). A lack of access to the formal banking services may inflict harms of different sorts in transferring and saving money by the poor, while obtaining short-term loans in various informal ways (e.g., Collard \& Kempson, 2005; Kempson \& Whyley, 1998; Kempson \& Whyley, 1999; Solo, 2008). Financial exclusion necessarily affects the lives of unbanked individuals adversely (Kamran \& Uusitalo, 2016a) because informal ways of managing ordinary money affairs don't provide a classic substitute to formal banking services (Kamran, 2017).

\section{Personal Harm}

The personal problems caused by financial exclusion in the lives of financially excluded include their worry of theft of money kept at home, potential of facing threats from illegal or informal lenders, wastage of time and feeling of deprivation (e.g., Kamran \& Uusitalo, 2016a; 2016b; Kempson \& Whyley, 1999). First, the unbanked commonly have appre- 
hension of robbery of money put at their home (Kamran \& Uusitalo, 2016a; Kempson \& Whyley, 1999). Likewise, individuals carrying considerable amount in their pocket fear burglary. Further, the wages paid in cash to poor individuals could be robbed in transit (Kamran \& Uusitalo, 2016a). Second, unbanked individuals can't access formal credit from banks and therefore, the only source of getting loans, in case of need, is approaching informal money lenders (Affleck \& Mellor, 2006; Byrne, McCarthy, \& Ward, 2005; 2007; Collard \& Kempson, 2005; Kempson \& Whyley, 1999). The lenders not only charge extremely high interest rates (Kempson \& Whyley, 1999; Mariwah, 2012), but exploit the poor individuals in different ways (e.g., Mariwah, 2012). The main negative outcome of borrowing from informal lenders is that the poor face threats and intimidation in the event of delay in loan instalments (e.g., Kamran \& Uusitalo, 2016a; Kempson \& Whyley, 1999). Third, personal consequence faced by the unbanked is wastage of time in various activities owing to a non-availability of a bank account. Kempson and Whyley (1999) have highlighted that unbanked individuals in the UK experienced issues with utility bills payment and handling of cheques. Some individuals decided not to open any account to maintain their control on their finances. But, techniques devised by unbanked individuals to manage their finances were found to be time consuming for them. Likewise, a study of Kamran and Uusitalo, (2016a) on the poor unbanked individuals in Pakistan revealed that the unbanked have to necessarily pay their utility bills in cash and by visiting the physical service facilities, which results in wastes of time.

\section{Social Harm}

The research suggests that unbanked individuals, in both developed and developing countries, undergo several sorts of social harm. Financial exclusion could adversely influence one's self esteem and can cause sense of deprivation and loss of connections in social domain (i.e., with friends and family members) (Kempson \& Whyley, 1999). Likewise, in the contemporary societies, people normally make purchases through debit or credit cards, while buying products by cash could raise doubts in other people minds that the money is not clean. This situation can also cause embarrassment and humiliation to unbanked people (Collard \& Kempson, 2005). Similarly, a study in the Pakistani context on unbanked individuals reported that unbanked individuals might be facing adverse social outcomes. The unbanked individuals have been reported to experience humiliation when others in their social contacts knew that they don't own a bank account. Equally, poor unbanked individuals are potentially vulnerable to shatter their social relationships with near ones. They might not maintain privacy of their savings. Their close relatives often ask for loan from them knowing that their relative has money. Refuting loan requests of close relatives potentially damages their relations with each other. Moreover, relations could also be harmed, if a close relative don't repay the money on agreed time (Kamran \& Uusitalo, 2016a; 2016b).

\section{Economic Harm}

The financially excluded individuals also experience several economic harms of exclusion. For example, in the UK context, individuals making utility bills payment in cash form nor- 
mally pay higher charges compared to those who pay by direct debit (Kempson \& Whyley, 1999; 1998). They also encounter issues in job offers in the UK because employers typically pay their wages to employees' bank accounts (Kempson \& Whyley, 1999). The unbanked also face issues in obtaining loans from formal sector as payments are made by direct debit, which they can't do (Kempson \& Whyley 1999, 1998). In addition, they are not able to buy things online, which could help them to save some money and time (Leyshon, Thrift, $\&$ Pratt, 1998). Also, the poor unbanked individuals normally face issues in saving money (Kamran \& Uusitalo, 2016a; Kempson \& Whyley, 1999) because money always remains in their possession and they are motivated to spend their money on less-important purchases. Lastly, poor unbanked individuals have been found to pay more costs during money transfers and occasionally they encounter problems in starting or running their personal businesses as their clients may offer to pay them through bank transfers (Kamran \& Uusitalo, 2016a).

\section{POTENTIAL ROLE OF ISLAMIC BANKS IN FINANCIAL INCLUSION OF THE POOR IN PAKISTAN}

Islamic banking system, due to its specific features, provides a comprehensive agenda for financial and social inclusion. It implies that the poor might not only be financially included, they would also be having better social position due to access to Sharī'ah compliant finance for employment, production and empowerment. It is accomplished by properly and equitably linking the business and economy with finance. There is empirical evidence that Islamic finance helps inclusion and financial sector development (Abedifar, Ebrahim, Molyneux, \& Tarazi, 2015). As discussed in the World Bank and Islamic Development Bank Group (2016), Islamic banking system has enabling features for inclusion by dint of its encouraging risk sharing, prohibiting interest, enhancing financial stability, and promoting investment in morally acceptable projects. These are advantages that could make it better adapted to the local environment, not only in Islamic countries, but also in lowand middle- income non-Muslim countries'. Rather, Islamic banking and finance has been aspired for creation, equitable distribution, and circulation of wealth in order to promote social justice and to satisfy customers' needs for Sharī'ah compliant investment opportunities (World Bank and Islamic Development Bank Group, 2016, p. 68).

A little research is carried out on the poor unbanked individuals in marketing domain (Kamran \& Uusitalo, 2016a; Koku, 2015). Financial exclusion necessarily affects welfare of the poor and harms them in numerous ways. It is particularly the case of Islamic banking institutions. The ethical dimension of Islamic finance ensures closer link between the real economy and finance. As each and every transaction for financing by the Islamic banks have to involve the real business and production activities, Islamic banks' supply of finance to the poor in agriculture, micro businesses and small agro-based industries has the capacity of leading to long-term sustainability of the economies. The greater ability of Islamic nance to avoid information asymmetry and moral hazard through mixing and matching among the numerous Islamic nance contracts, the financing facility provided is used only for their prescribed purposes. 
Islamic banking has a great potential to serve the excluded and marginalized individuals in Pakistan and elsewhere. Due to SRI friendly nature, Islamic banking and finance system can serve the real purpose of financial intermediation as a means to create sustainable value in the real economy. It could be more effective in resource mobilization from the people who avoid interest and are interested in ethical investment. The partnership based contracts as also the exchange contracts including trade related modes like based muräbahah, mu'ajjal, salam and istisna $\bar{a}^{6}$, and ijärah (leasing) can play their role in alleviating exclusion of the poor and developing the real economy. But the Islamic banks and financial institutions need to use them while observing their Sharī'ah essentials in letter and spirit (Ayub, Khan, \& Rashid, 2018). As per the theory of Islamic banking, profit rates given by Islamic banks should be higher than the profits given by the conventional banks. Similarly, they may provide finance more to the commodity sectors than merely financing the deficit of the public sector. Practically, however, while the profits given by Islamic banks in Pakistan are less than the conventional banks profit, their financing for small agriculture units and the SMEs is negligible (Ayub et al., 2018).

Many authors maintain that Islamic banking system has progressed well in the last four decades, which provides an alternative banking system to banking customers (e.g., Zaman, Mehmood, Aftab, Siddique, \& Ameen, 2017). However, many authors have also pointed out to the unsatisfactory performance of Islamic banks in serving the masses in Muslim countries. Ahmad (2015) maintains that Islamic banks failed to play their part in enhancing financial inclusion and development of Muslim countries. Their role has been rather unsatisfactory in the last four decades.

This suggests that Islamic banks are not operating according to the true spirit of Islam, as Islamic business values promote equality and marketplace justice. A number of authors have expressed serious concerns in this regard. Buiter (2009) expresses concern in The Financial Times in the following words: What we need is the application of Islamic finance principles, in particular a strong preference for profit-loss and risk-sharing arrangements and a rejection of "rib $\bar{a}$ " or interest-bearing debt instruments.- the sham pseudo-Islamic Shar' 'ah-compliant instruments were window-dressing, that were mathematically equivalent to conventional debt and mortgage contracts, but met the letter if not the spirit of Shar' 'ah law, in the view of some tame, pliable - Shari' 'ah scholars.

Exclusion of poor from the basic banking services is discriminating to them as they encounter problems in handling their daily finances (Kamran \& Uusitalo, 2016a; 2016b). Islamic banks can be helpful by operating in line with their true ideology for ensuring marketplace justice and equality for the poor unbanked, and for mitigating their sufferings by facilitating their inclusion into Islamic banking system. This way, Islamic banks can increase social and public welfare (Dusuki, 2008).

The barriers to banking and unwelcoming outcomes of exclusion are drawn from the general financial exclusion literature owing to a lack of research on the issue in Islamic banking stream. It is important to note, however, that customers expressed akin barriers in the adoption of Islamic banking in Pakistan. For example, a study by Zaman et al. (2017) finds that customers lack of information regarding Islamic banks, questions about their Sharī'ah 
legitimacy, and quality of banking services are barriers to Islamic banking adoption. IFIs' ideology is to focus on practices led by Islamic thought (Mohammed, 2013), which value meeting financial, normative and social welfare outcomes. This implies that while a business exists to earn profit by Islamic banks, they must also focus on the wellbeing of society (Azid Asutay, \& Khawaja, 2008; Choudhury, Azid, \& Klasra, 2006).

The widespread unbanked population represents an opportunity for Islamic banks to enhance their customer base and legitimacy and public wellbeing. Currently, total market share of Islamic banks is just 15\% in the banking industry of Pakistan (State Bank of Pakistan, 2018). This suggests a poor performance of Islamic banks in a Muslim country (i.e., Pakistan) where almost $96 \%$ population are Muslims practicing rituals. Islamic banks can tap this opportunity by serving the unbanked individuals. They should address to remove impediments faced by the poor in the way of adoption of basic banking services. This paper suggests viable managerial steps for removing the impediments to banking services adoption and for expansion of Islamic banking in Pakistan.

The facility of basic banking account could facilitate the unbanked poor to mitigate their harm which they risk facing due to financial exclusion (Kamran \& Uusitalo, 2016a; 2016b). Islamic banks can certainly help to remove barriers to basic banking to the unbanked poor, which can alleviate the powerlessness of the poor unbanked individuals that they face in the absence of bank account. First, literature on financial exclusion highlights that poor unbanked individuals commonly encounter problems in accessing physical bank branches as their location is not in their neighborhood. Over half of the Pakistani population lives in villages (World Bank, 2015) while banks branches are only in cities and towns. As a result, many poor living in low-income remote areas also find it difficult to reach to physical bank branches. As Islamic banks are required to deal in real goods, business and production activities, they should open at least half of their new branches to geographically remote area which could strengthen the link between the real economy and finance and serve the needs of unserved poor unbanked customers.

Second, people in general lack knowledge about Islamic banks; but poor individuals specifically lack education regarding banks (Kamran \& Uusitalo, 2019; Zaman et al., 2017). Many Muslim unbanked individuals don't own a conventional bank account because they consider it against the Islamic law which prohibits interest based banking. The lack of knowledge about Islamic banks among poor customers further stimulates them to remain unbanked. However, their exclusion causes them harm of various sorts. Islamic banks should start various types of educational programs to enhance poor unbanked individuals' awareness regarding the advantages of adopting and operating an Islamic bank account.

Third, poor unbanked individuals frequently face various risks and threats from informal lenders (Kamran \& Uusitalo, 2016a; Kempson \& Whyley, 1999). The literature on financial exclusion suggests that poor individuals commonly find it difficult to access credit (e.g., Kironget, 2014). They either turn to social networks to obtain short term loans or acquire it from informal money lenders. It is reported that merely $2 \%$ of the economically underprivileged population has an access to micro-finance from banks and other financial service institutions in Pakistan (Kironget, 2014; Nenova, Niang, \& Ahmad, 2009). The poor indi- 
viduals also require loans, but their inability to access loans from banks incite them to get loans from various informal sources which commonly cause them harm (Kamran \& Uusitalo, 2016a; Kempson \& Whyley, 1999). Therefore, Islamic banks should offer micro-credit to the poor in Pakistan. This can help to enhance financial inclusion of the poor and also facilitate them in mitigating their sufferings by providing interest free finance. Four, poor unbaked individuals commonly face issues in saving money in a variety of informal ways (e.g., Kempson \& Whyley, 1999) while their smooth economic lives often depend on savings. Access to an Islamic basic bank account can help them to eliminate fear of safety and privacy of their savings.

Fifth, literature on financial exclusion reveals that poor individuals face unfairness from banks frontline employees. The poor report unwelcoming behaviour of customer service staff and a substandard and discriminatory service experience. The Islamic banks customers also express their concerns about the services provided at Islamic banks (Zaman et al., 2017). Therefore, Islamic bank branches staff should be trained to deal with their customers in a polite manner and they should be given specific training in dealing with the poor individuals because they often require extra help in dealing with various banking affairs.

Sixth, poor unbanked individuals are commonly interested to open a basic bank account if they are facilitated properly (Solo, 2008). In case of Muslim countries like Pakistan, people are generally positive towards Islamic banking services owing to the element of interest $(r i b \bar{a})$ involved in conventional banking (Zaman et al., 2017). Therefore, there is a huge potential for Islamic banks to design proactive strategies to serve the un-served individuals in Pakistan. In so doing, Islamic banks can enhance their customer base and could improve poor individuals' welfare. For this, proactive strategies need to be designed through a thorough understanding of the poor unbanked individuals banking needs.

Finally, Islamic banks may also avail the unique institution of 'waqf' in the framework of Islamic social disciplines. Waqf that is the unique source of funding for socio-economic and broad based development of the societies is an Islamic endowment of asset to be held in trust and used for welfare and charitable purposes. In Islamic history, waqf has been used for broad based socio-economic growth and development of Muslim societies. Funds mobilized through this unique source could be used for financing the extreme poor in agriculture and SME for providing qard al-ḥasan (Khan \& Nur Sakinah, 2017).

\section{CONCLUSION}

Islamic banking and finance institutions need to realize the potential of Islamic system of finance that upholds social justice, equality in opportunities, economic prosperity and inclusivity. The noble objective of alleviating exclusion can be accomplished by properly and equitably linking the business and economy with finance. Islamic banks need to finance the commodity producing sectors like small farms in agriculture, micro businesses and the SMEs. However, Islamic banking and finance has yet to make a significant contribution to financial inclusion and socio-economic development (Abedifar et al., 2015).

So far, Islamic financial institutions have not been able to avail the opportunity of enhancing their outreach by involving the people who avoided banking system due to inter- 
est, and by providing a helping hand to the States in alleviating poverty. There is a large concentration of contracts like organized tawarruq, sale of debts and 'debt like sukük', financial derivatives, bills discounting, etc that can never be helpful in realizing the objective of alleviating exclusion and poverty. For this, two approaches have been recommended in the literature i) by promoting risk-sharing contracts - providing a viable alternative to conventional debt-based financing; and ii) by using specific wealth redistribution instruments ${ }^{1}$ (World Bank and Islamic Development Bank Group, 2016, pp. 17-40).

To effectively achieve the objective of financial and social inclusion that is considered to be the ultimate objective of Islamic banking, the World Bank and Islamic Development Bank Group (2016) recommends introducing innovative risk-sharing products and services, rather than replicating conventional risk-transfer products; unifying cross-country Sharī'ah rulings on Islamic finance; enhancing access to Islamic finance; developing Islamic finance human resources/professionals and enabling regulatory and supervisory environment to address systemic risk across jurisdictions. So far, Islamic banks operations have been "close to conventional banks through products like tawarruq ${ }^{2}$, commodity murābahah, Islamic repos, and asset-based securities, which some argue are detached from the real economy and move too far away from the theoretical underpinnings of Islamic economics" (pp. 68-69).

Thus the key measure for promoting financial inclusion is promoting Islamic finance, which in turn, can be effective for enhancing shared prosperity. It can be accomplished by the steps like implementing a sound regulatory framework for Islamic banks, harmonizing the Sharī'ah standards and deciding a suitable mechanism for developing Islamic financial products. Research on poor unbanked individuals in the context of conventional and Islamic banking services is lacking. In order to develop effectiveness and achieve the potential of Islamic finance in reducing inequality and enhancing social inclusion, the World Bank and Islamic Development Bank Group (2016) recommends:

- To enhance harmonization, implementation and enforcement of regulations;

- To create institutions that provide credit and other information to support equity-based finance, particularly for Micro, Small and Medium-Sized Enterprises (MSMEs);

- To develop capital markets and sukūk products to help finance large infrastructure projects; and

- To provide regulatory recognition of products from other jurisdictions to expand the markets through cross-border transactions

Finally, the following section offers some future research avenues in the context of Islamic banking services.

\section{Future Research Avenues for Enhancing Inclusion through Islamic Banking}

The literature suggests several barriers to banking for the poor individuals. The literature also addresses the unbanked individuals' sufferings due to their financial exclusion (e.g.,

\footnotetext{
${ }^{1}$ For the need of the 'shared Prosperity' see World Bank and Islamic Development Bank Group, 2016

${ }^{2}$ Tawarruq is the process of buying on credit and selling to to any third party on cash at lower price, with the aim to obtain cash. This is the classical form of tawarruq, which is permissible. Organised tawarruq, where the bank plays both the roles of seller and buyer, is not permissible according to the majority of contemporary fuqahā' as also Islamic Fiqh Councils of Jeddah and Makkah.
} 
Kamran \& Uusitalo, 2016a). It is rather unclear how banks management reacts to financial exclusion of poor individuals through their policies and other initiatives. Future study could explore how Islamic banks top management perceives serving the poor unbanked in Pakistan and elsewhere. Second, poor individuals are stigmatized and marginalized in various service settings (Fisk et al., 2016). Islamic banks claim to be more responsible than the conventional banks and hence the former's customers should have different perception regarding their frontline staff members. Therefore, there is a possibility to explore customers' perceptions regarding the banks frontline employees and their service quality. In addition, the literature reports a discussion on low-income customers' perception about conventional banks, but ignores to explain how frontline employees perceive serving the economically disadvantaged individuals. Therefore, there is a potential to investigate Islamic banks frontline service employees perceptions and attitude towards their poor customers.

Third, Pakistan is a Muslim country with a massive following of Islamic teachings, at least with regard to prohibition of interest. It seems that many persons who do own a bank account might not be adopting Islamic banking services in Pakistan due to some misgivings or possibly the low level of Shari' ah compliance of Islamic banks [IBIs have only $15 \%$ share of total financial services industry in the country]. Therefore, investigating resistance to Islamic banks could yield interesting and practically useful findings for Islamic banks to enhance their services and outreach.

\section{REFERENCES}

Abedifar, P., Ebrahim, S. M., Molyneux, P., \& Tarazi, A. (2015). Islamic banking and finance: Recent empirical literature and directions for future research. Journal of Economic Surveys, 29(4), 637-670. doi: https://doi.org/10.1002/9781119158424.ch4

Affleck, A., \& Mellor, M. (2006). Community development finance: A neo-market solution to social exclusion? Journal of Social Policy, 35(2), 303-319.

doi: https://doi.org/10.1017/s0047279405009542

Ahmad, Y. A. (2015). Does Islamic banking help in economic development of Muslim countries? Journal of Islamic Business and Management, 6(2), 19-39.

Ayub, M. (2018). Maqāsid Realisation in Islamic Finance: Components of Framework for Measurement Index. Journal of Islamic Business and Management, 8(1), 1-9. doi: https://doi.org/10.26501/jibm/2018.0801-001

Ayub, M. Khan, K., \& Rashid, A. (2018). Strengthening the Sharī'ah governance for Islamic banking institutions: The case of Pakistan. The Journal of Islamic Finance Accountancy (JOIFA), 2(1), 23-34.

Azid, T., Asutay, M., \& Khawaja, M. J. (2008). Price behaviour, vintage capital and Islamic economy. International Journal of Islamic and Middle Eastern Finance and Management, 1(1), 52-68. doi: https://doi.org/10.1108/17538390810864250

Brennan, C. (2006). Empowering vulnerable consumers in the KBE: Taking forward policy, knowledge and a new alliance for consumer education. Paper presented at the Institute for Advanced Studies workshop: Consumers and the Knowledge-Based Economy, Lancaster University, Lancaster, UK. 
Buiter, W. (2009). Islamic finance principles to restore policy effectiveness. Financial Times, London, UK.

Byrne, N., McCarthy, O., \& Ward, M. (2005). Meeting the Credit needs of low-income groups: Credit unions-v-moneylenders (Vol. 5). Dublin, Ireland: Combat Poverty Agency.

Byrne, N., McCarthy, O., \& Ward, M. (2007). Money-lending and financial exclusion. Public Money and Management, 27(1), 45-52. doi: https://doi.org/10.1111/j.14679302.2007.00554.X

Carbo, S., Gardener, E. P., \& Molyneux, P. (2007). Financial exclusion in Europe. Public Money and Management, 27(1), 21-27.

Choudhury, A. M., Azid, T., \& Klasra, M. A. (2006). Knowledge-induced technological change: A study involving the automobile innovation in Malaysia with layers of techniques. International Journal of Social Economics, 33(11), 744-765. doi: https://doi.org/10.1108/03068290610705661

Claessens, S. (2006). Access to financial services: A review of the issues and public policy objectives. The World Bank Research Observer, 21(2), 207-240.

Collard, S., \& Kempson, E. (2005). Affordable credit: The way forward. Bristol, UK: Policy Press.

Demirguc-Kunt, A., Klapper, L., Singer, D., \& Van Oudheusden, P. (2015). The global findex database 2014: Measuring financial inclusion around the world. Washington, DC, WA: The World Bank.

Dusuki, A. W. (2008). Understanding the objectives of Islamic banking: A survey of stakeholders' perspectives. International Journal of Islamic and Middle Eastern Finance and Management, 1(2), 132-148. doi: https://doi.org/10.1108/17538390810880982

Fisk, R. P. P., Anderson, L., Bowen, D. E., Gruber, T., Ostrom, A., Patrício, L., ... \& Sebastiani, R. (2016). Billions of impoverished people deserve to be better served: A call to action for the service research community. Journal of Service Management, 27(1), 43-55. doi: https://doi.org/10.1108/josm-04-2015-0125

Hasan, H., Ali, S. S., \& Muhammad, M. (2018). Towards a Maqāsid al-Sharī'ah Based Development Index. Journal of Islamic Business and Management, 8(1), 20-36. doi: https://doi.org/10.26501/jibm/2018.0801-002

Kamran, S. (2017). ROSCAs role in facilitating control to the unbanked: Evidence from Pakistan. Electronic Journal of Business Ethics and Organization Studies, 22(2), 4-13.

Kamran, S., \& Uusitalo, O. (2016a). Vulnerability of the unbanked: Evidence from a developing country. International Journal of Consumer Studies, 40(4), 400-409. doi: https://doi.org/10.1111/ijcs.12277

Kamran, S., \& Uusitalo, O. (2016b). How the unbanked cope with financial exclusion: Evidence from Pakistan. Journal of Financial Services Marketing, 21(2), 153-165. doi: https://doi.org/10.1057/fsm.2016.6

Kamran, S., \& Uusitalo, O. (2019). Banks' unfairness and the vulnerability of low-income unbanked consumers. The Service Industries Journal, 39(1), 65-85.

doi: https://doi.org/10.1080/02642069.2018.1436704 
Karnani, A. (2009). Romanticising the poor harms the poor. Journal of International Development: The Journal of the Development Studies Association, 21(1), 76-86. doi: https://doi.org/10.1002/jid.1491

Kempson, E. (2006). Policy level response to financial exclusion in developed economies: Lessons for developing countries. Report of Personal Finance Research Centre, University of Bristol, Bristol, UK.

Kempson, E., \& Whyley, C. (1998). Access to current accounts: A report to the British Bankers' Association. London, UK: British Bankers' Association.

Kempson, E., \& Whyley, C. (1999). Kept out or opted out? Understanding and combating financial exclusion. Bristol, UK: Policy Press.

Kempson, E., Atkinson, A., \& Pilley, O. (2004). Policy level response to financial exclusion in developed economies: Lessons for developing countries (p. 49). Bristol, UK: Department for International Development (DFID).

Kempson, E., Whyley, C., Caskey, J., \& Collard, S. (2000). In or out? Financial exclusion: A literature and research review. London, UK: Financial Services Authority.

Kennedy, A. M., \& Laczniak, G. R. (2016). Conceptualisations of the consumer in marketing thought. European Journal of Marketing, 50(1/2), 166-188.

doi: https://doi.org/10.1108/ejm-10-2014-0608

Khan, K. \& Nur Sakinah N. N. S. (2017). Promotion of agricultural and small business financing through qard hasan in Pakistan (ISRA Research Paper (IRP) No. 97/2017). Retrieved from https://bit.ly/2BN5Zlv

Kironget, L. (2014). Pakistan mobile money gap analysis. Retrieved from https://bit.ly/2N1Q0Q8

Kochar, R. (2015). A global middle class is more promise than reality: From 2001 to 2011, nearly 700 million step out of poverty, but most only barely. Pew Research Center/Global Attitudes and Trends. Retrieved from https://pewrsr.ch/1NP1G6y

Koku, P. S. (2015). Financial exclusion of the poor: A literature review. International Journal of Bank Marketing, 33(5), 654-668. doi: https://doi.org/10.1108/ijbm-09-20140134

Kotler, P., \& Levy, S. J. (1971). Demarketing, yes, demarketing. Harvard Business Review, 79, 74-80. doi: https://doi.org/10.4135/9781452231372.n7

Leyshon, A., Thrift, N., \& Pratt, J. (1998). Reading financial services: Texts, consumers, and financial literacy. Environment and Planning D: Society and Space, 16(1), 29-55. doi: https://doi.org/10.1068/d160029

Mariwah, S. (2012). Shylock vs. Antonio: Informal money lending in rural communities in the Jaman North District, Ghana. Journal of Sustainable Development in Africa, 14(2), 150-161.

Mohammed, J. A. (2013). An Islamic perspective of corporate social responsibility. Paper presented at the Global Conference on Business, Economics and Social Sciences Research, Kuala Lumpur, Malaysia.

Rashid, A., Riaz, M., \& Zaffar U. A. (2018). Are Islamic banks really different from conventional banks? An investigation using classification techniques. Journal of Islamic 
Business and Management, 8(1), 37-52. doi: https://doi.org/10.26501/jibm/2018.0801003

Rendtorff, J. D. (2009). Basic ethical principles applied to service industries. The Service Industries Journal, 29(1), 9-19. doi: https://doi.org/10.1080/02642060802116404

Solo, T. M. (2008). Financial exclusion in Latin America-or the social costs of not banking the urban poor. Environment and Urbanization, 20(1), 47-66. doi: https://doi.org/10.1177/0956247808089148

State Bank of Pakistan. (2018). Islamic banking bulletin - March 2018. State Bank of Pakistan, Karachi, Pakistan.

Wang, J. J., \& Tian, Q. (2014). Consumer vulnerability and marketplace exclusion: A case of rural migrants and financial services in China. Journal of Macromarketing, 34(1), 45-56. doi: https://doi.org/10.1177/0276146713508137

World Bank and Islamic Development Bank Group. (2016). Global report on Islamic finance: Islamic finance: A catalyst for shared prosperity. Washington, DC, WA: Islamic Development Bank Group. doi: https://doi.org/10.1596/978-1-4648-0926-2

World Bank. (2005). Indicators of financial access-household-level surveys. World Bank, Washington, DC, WA.

World Bank. (2015). Rural population (\% of total population). Retrieved from https://bit.ly/2E9ihHe

World Bank. (2018). Financial inclusion overview. Retrieved from https://bit.ly/1Nkdk7f

Zaman, Z., Mehmood, B., Aftab, R., Siddique, M. S., \& Ameen, Y. (2017). Role of Islamic financial literacy in the adoption of Islamic banking services: An empirical evidence from Lahore, Pakistan. Journal of Islamic Business and Management, 7(2), 230-247. doi: https://doi.org/10.26501/jibm/2017.0702-006 